\title{
SUSTAINABLE MANAGEMENT OF MANGO NUTRITION FOR BETTER YIELD AND QUALITY
}

\author{
Muhammad KHAN ${ }^{1, *}$, Niaz AHMED ${ }^{1}$ \\ *E-mail: mehboobkanjoo@aol.com
}

Received: Aug. 17, 2020. Revised: Oct. 29, 2020. Accepted: Nov. 06, 2020. Published online: Jan 29, 2021

\begin{abstract}
Optimum supply of macro and micronutrients is of critical importance in improving the yield and quality of horticultural crops. Alike, the quality and yield of mango plants significantly increase by balanced application and uptake of macro and micronutrients. However, soil type and characteristics are important factors that directly influence the bio-availability of these nutrients to the plants. In addition, variability in climate has an impact on mango yield in the current scenario. Many scientists have found that mango cultivation in saline soils is a major obstacle to achieving the desired yield and improving quality. Overdose of fertilization is the major factor for the development of saline soils, furthermore, rise in climate temperatures is also a major factor. Therefore, to overcome this problem, nutrient management and the use of balanced fertilizer are the important factors to be controlled. Thus, this review focuses on the performance and importance of essential macro and
\end{abstract}

micronutrients to improve the yield and quality of mango fruits. To understand the effective use of macro and micronutrients, the positive and negative impacts of the nutrients are explained. It is suggested that analyzing the soil, mango fruits, and mango plant leaves for their nutrient status can be useful to formulate fertilization strategies for higher fruit production and quality. Research and development, along with agricultural extension, should focus more on introducing genetically effective mango varieties to improve nutrient and water utilization efficiency.

Keywords: nutrient management; fruit quality; mango production; yield.

\section{INTRODUCTION}

Mango (Mangifera indica L.), most cultivated fruit in tropical region, and it is categorized in the plant family named as "Anacardiaceae" and it is found to be of South East Asia

\footnotetext{
${ }^{1}$ Department of Soil Science, Faculty of Agricultural Sciences and Technology, Bahauddin Zakariya University, Multan 60800, Pakistan
} 
origin (Douthett, 2000). Mango is the second major fruit after citrus in Pakistan and is widely known as 'king of fruits' (Usman et al., 2003). To determine the quality of mango fruit, the size, total sugar contents, acidity and $\beta$-carotene, total soluble solids (TSS), ascorbic acid, sugar-acid ratio and golden yellow color must be observed.

Owed to disease, insufficient nutrients and improper management of fertilizer, mango fruits produce low yields and quality that are unsatisfactory for export or to be sold locally (Gurjar et al., 2015). Further, higher physical damages and deteriorated quality have been observed in mango farms. Imbalanced fertilization, including micronutrients, improper cultural practices and inadequate handling of trees result in reduced quality farms. In accordance with horticultural experts, it is necessary to use basic nutrients along with micronutrients to get the best quality of mango fruit. The micronutrients are often used as foliar application to reduce nutritional deficiencies and to improve the quality of mangoes (Sankar et al., 2013). Although, owing to the type of soil and climate, Pakistan is considered suitable for good quality and production of mango fruit; however, yet, the country is far behind achieving the potential yield. There are many factors which influence the sustainability of mango farms and affect the quality and production of mangoes, such as soil characteristics, climate circumstances and fertilization stratagems, which are being discussed in this review.

\section{Soil type}

Soil characteristics directly influence the mango cultivation. Plants use soil as inert medium for growth. Nutrients availability is regulated in soil through root growth and soil effects the functional activities of the plants. Several types of soil, as of low fertility and lowgrowing soils to well-fertile deeper soils (Red Cross Nosium), can be used for mango growth (Dirou, 2004). Though, cultivation and growth of mango is influenced by the physical and chemical characteristics of the soil. Soil of less fertility, light and of good drainage properties are deliberated as good soils for mango production because mango fruit cannot produce good fruit color in highly fertile soils (Madonsela, 2019) and such soils can also have nutritional problems (Paul and Duarte, 2011). The soil which are sandy clay, flat and deep, with sufficient organic matter, is considered suitable for mango plantation (Magalhaes and Borges, 2000). In addition, sandy loam, sandy, lateritic and alluvial soils are appropriate for the cultivation of mango trees. Moreover, soils with a considerable depth of 2-2.5 m, having a $\mathrm{pH}$ range from neutral to alkaline, with specific value point as 5.5-7.5 (Bally, 2006), are ideal for growing and cultivating good amounts of organic manganese (Chowdhury and Mehta, 2010). It was reported that cultivation of mango trees on sandy 
loam and loam soils advantages to improve the skin color of mango fruit during the period of ripening and reduces the rate of mass thawing of the fruit, cf. soft nose or jelly seeds (Bitange et al., 2020). In addition, mango trees have also been reported to be sensitive to sodic and saline conditions (Madonsela, 2019). The hardpan of the soil under the subsoil surface layer or sometimes known as plow layer should be broken as it reduces the mango tree root infiltration into the soil (Paull and Duarte, 2011). Therefore, for the high yield and quality of mango fruit, the selection of suitable soil is a main factor to consider.

\section{Soil pH}

Trees of mango can withstand a $\mathrm{pH}$ range from 5.5 to 7.5 because they can tolerate alkaline conditions (Bally, 2006). It has been reported that at high $\mathrm{pH}$, the growth and quality of mango reduces because of the unavailability of trace elements, which adversely affects the quality of the mango fruit. Low soil $\mathrm{pH}$ reduces the availability of nutrients for trees. When this happens, it is not advantageous to apply more fertilizer to the trees, because it often leads to leaching and fixation of the nutrients. To reduce this problem, it is necessary to add lime to the soil of fruit plants to lower the $\mathrm{pH}$ of the soil. Therefore, soil sample for the analysis of basic parameters including soil $\mathrm{pH}$ in the laboratory is important. So that we may know the requirement for the establishment of garden. Regular cultivation and production of mango has been reported by Madonsela (2019), in calcareous soil type (>38\% $\mathrm{CaCO}_{3}$ ), according to $\mathrm{pH} 9$ in Israel. According to Usman et al. (2003), $\mathrm{pH}$ ranges from 5.5 to 8.7 has been reported for mango production in Pakistan. Soil having characteristics of stickiness, waterlogging conditions and hardpan below subsurface should be avoided to obtain higher mango production. Likewise, the $\mathrm{pH}$ of the soil helps in selecting criteria for establishing mango plantation.

\section{Soil salinity}

Owing to the moderate tolerance of mango plants against saline conditions, soil salinity is the major concern for reduced mango fruit production (Elsheery et al., 2020). Leaves tip and edge burning and leave curling of mango plants occur in severe saline conditions, subsequently leading to plant death. The effect of salinity in growth and development cycle of mango trees is the same and their symptoms are same as appear in plants other than mango trees (Elsheery et al., 2020). The rate of transpiration in mango trees dropped sharply when the salinity period increases maximum (Schmutz and Ludders, 1993). Photo assimilation process in mango plants has been found to susceptible for higher salinity levels (Schmutz, 2000). However, the extent of salinity tolerance in mango rootstock and fruit production has not been studied well (Maas and Grattan, 1999). Therefore, a diversity in the mango varieties should be induced to 
develop salt tolerant rootstock (Dinesh, 2003). Nevertheless, a calculated data is required containing critical values of salinity in soil and water, for obtaining the required quality and production of mango fruit.

\section{Climatic conditions}

Temperature and available water are considering as important factors that influence the mango production by affecting the vegetative growth, initial flowering and occurrence of disease in the mangoes (Madonsela, 2109; Davenport, 2006). Ideal temperature range, which is required during growth season is $24-30^{\circ} \mathrm{C}$, with 890 to $1015 \mathrm{~mm}$ rainfall and maximum humidity. The areas receiving inadequate $(254 \mathrm{~mm})$ to heavy rainfall $(2540 \mathrm{~mm})$ are also recognized appropriate for mango plantation. During flowering, rainfall is dangerous owing to reduced pollinating activities (Choudhary and Mehta, 2010).

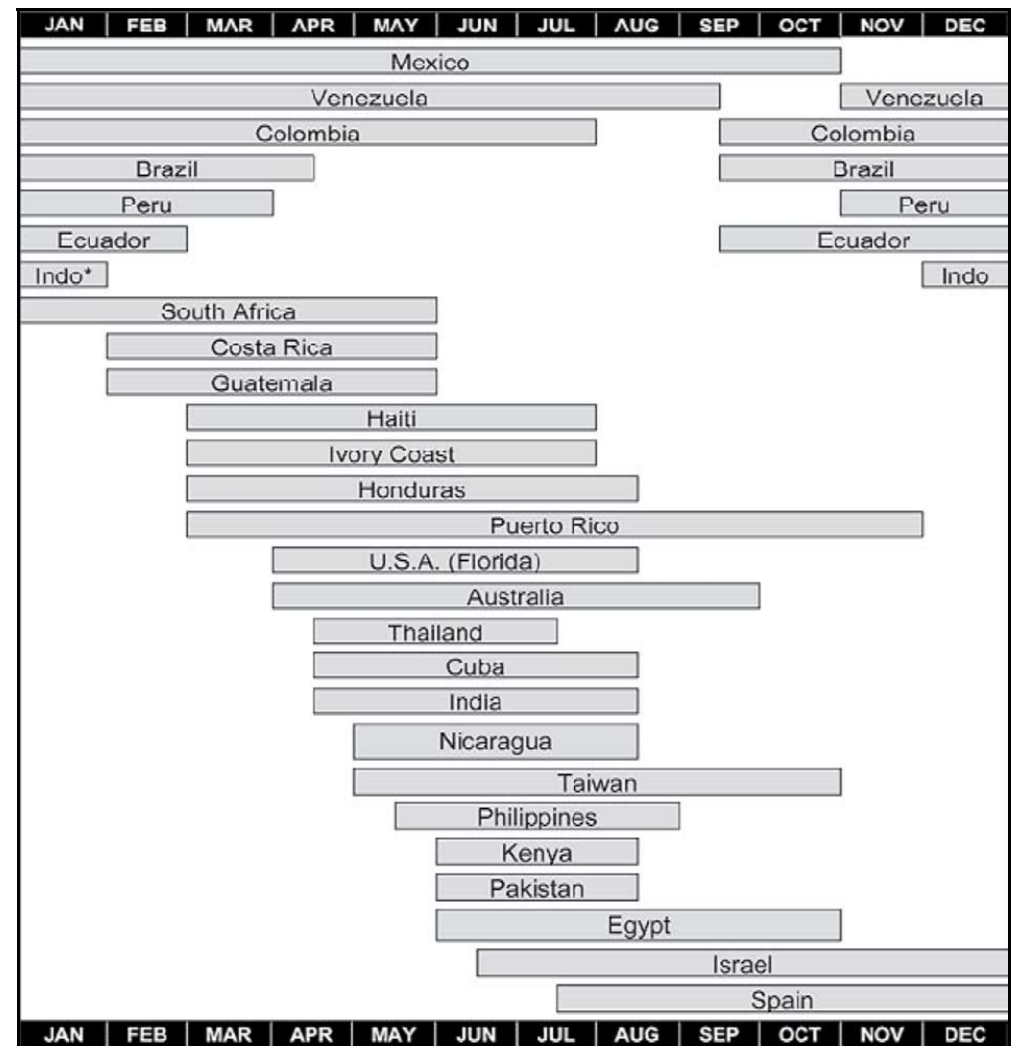

Figure 1 - Data of several countries with different seasons (Information source: Saúco, 2004; Siddiq et al., 2017)

Mango trees have the capability to withstand flooding conditions. Nonetheless, rain is needed for the initiation of flowering and fruits but it is not possible to initiate flowering without dry span. Internal osmotic 
pressure of the plant helps to keep the leaves and lactiferous cells turgid (Fisher et al., 2012). Due to the deep root system, by which plants absorbs nutrients and water from deep into the soil, makes the mango trees drought tolerant (Paul and Duarte, 2011). Dry periods are necessary to increase flowering in the mango plant (Paul and Duarte, 2011). The climatic condition in different countries varies due to different time zone; the Fig. 1 justifies the mango plantation.

\section{Fertilization of mango plants Young trees}

A pit size of $60 \times 60 \times 60 \mathrm{~cm}$ is recommended for the mango plantation. Fertilizer dosage recommendation for the aforementioned pits varies from area to area. The fertilizers dose required in these pits depends upon the qualitative analysis of the soil and the volume of soil existing in the pits. Mango plants can grow in the soil of low fertility, but a sufficient amount of fertilizer added to the soil and uptake nutrients helps the better plant growth and mango fruit. To maintain the plant health and proper growth of plant canopy, the fertilizer is applied in the initial stages of plant growth. The first application of fertilizer is generally applied according to the soil analysis. Table 1 shows that a small dose of fertilizer is applied to young mango plants. The nitrogen $(\mathrm{N})$, phosphorus $(\mathrm{P})$ and potassium $(\mathrm{K})$ are applied twice a year. However, $\mathrm{P}$ and $\mathrm{K}$ are used only if they are insufficient. The recommended dosage of these fertilizers should incorporate into the soil or it should be applied to the plant rows through broad casting method of fertilizer application (Andrade, 2004; Sousa et al., 2004). The fertilization with macronutrients should be proceeded to the plants at plantation stage or should be applied on various growth stages depending on the analyses of the soil and mango leaves.

The fertilizer impacts on the plants varies with many factors, including method and time of application, source of fertilizer, climatic conditions, variety of cultivar, moisture conditions of soil and growth rate and linear condition of tree. Stassen et al. (1999) stated that a plant of 6 years of age contains $29.6 \%$ of $\mathrm{P}$ in the dry matter of plant leaves. Similarly, $16.6 \%$ of $\mathrm{P}$ was found in new branches, $14.9 \% \mathrm{P}$ was investigated in fruit, $11.7 \% \mathrm{P}$ in wood, 9.3\% $\mathrm{P}$ inside the bark and $17.9 \% \mathrm{P}$ was inside the roots. It was discovered that a large portion of $\mathrm{P}$ was found within leaves of the plants, while $70.4 \%$ of $\mathrm{P}$ was found in the rest of the vegetative plant parts. In the South Pacific areas, young mango plants were supplied with NPK dosage of $0.4-0.2-0.2 \mathrm{~kg}^{-1}$ tree $^{-1}$ year $^{-1}$ during the age of $1 \mathrm{st}$ to $5^{\text {th }}$ years, whereas, 0.7-0.7-0.7 kg-1 tree $^{-1}$ year $^{-1}$ was applied later on. The recommended NPK dosage for plants of 1-4 years' age was $0.4-0.2-0.2 \mathrm{~kg}^{-1}$ tree $^{-1}$ year $^{-1}$ and for 5-10 years' age was 1.3-0.55$0.85 \mathrm{~kg}^{-1}$ tree $^{-1}$ year $^{-1}$ in the North Pacific region. In Taiwan, the amount of fertilizer is applied in two equal splits, i.e., in marble and after harvest. The fertilizers are applied though 
broadcasting, side coating, banding and hole application. The dose of $\mathrm{N}$,
$\mathrm{P}$, and $\mathrm{K}$ fertilizers increases with increasing age of the plants.

Table 1 - Fertilization of nitrogen (N), phosphorus (P) and potassium (K) to young mango trees in various countries

\begin{tabular}{|c|c|c|c|c|c|}
\hline \multirow[t]{2}{*}{ Country } & \multirow{2}{*}{$\begin{array}{l}\text { Tree age } \\
\text { (year) }\end{array}$} & \multicolumn{3}{|c|}{$\begin{array}{l}\text { Amounts of nutrients } \\
\left(\mathrm{g} \text { plant }^{-1} \text { year }^{-1}\right)\end{array}$} & \multirow[t]{2}{*}{ Reference } \\
\hline & & $\mathbf{N}$ & $\mathbf{P}$ & K & \\
\hline Brazil & $2-3$ & 210 & 160 & 120 & Silva et al. (1996) \\
\hline China & $7-9$ & 400 & 125 & 320 & Xiuchong et al. (2001) \\
\hline India & $7-9$ & 700 & 500 & 700 & Choudhary and Mehta (2010) \\
\hline $\begin{array}{l}\text { Queensland, } \\
\text { Australia }\end{array}$ & 2 & 400 & 500 & 360 & Sanewski (1991) \\
\hline Mexico & $1-4$ & 200 & 100 & 100 & Crane et al. (2009) \\
\hline $\begin{array}{l}\text { Southern Pacific } \\
\text { region }\end{array}$ & $1-5$ & 400 & 200 & 200 & Crane et al. (2009) \\
\hline $\begin{array}{l}\text { Northern Pacific } \\
\text { region }\end{array}$ & $1-4$ & 400 & 200 & 200 & Crane et al. (2009) \\
\hline Taiwan & $1-2$ & 150 & 20 & 120 & Crane et al. (2009) \\
\hline
\end{tabular}

\section{Bearing trees}

Mango fertilizer is essential for the suitable health of trees, the initiation of flowers, the onset and avoidance of alternative effects. Excessive use of fertilizers can lead to continuous vegetative growth of bearing mango trees and can cause reduction in flowers and lower fruit production and also the incidence of physical damages in mango fruit may be increased (Nguyen et al., 2004).

Similarly, improper application of fertilizers in mango plants can induce deficiencies and toxicities of nutrient and can result in stunted growth. Thus, fertilization strategies must be managed according to the need of the plants in order to obtain higher production of mango fruits (Crane et al., 2009).

Less than $30 \%$ of the mango farms in the Central Pacific regions are supplied with fertilizers. Crane et al.
(2009) reported that $86 \%$ mango farms are fertilized in South Pacific regions, whereas, $56.7 \%$ are supplied once a year, and $39.5 \%$ are supplied with fertilizers twice a year. The mango orchards, where fertilizers are used regularly, there has been a noteworthy difference in time, content, quantity and source of fertilizers. In Central Pacific regions, an NPK dose of 1.1-0.4-0.9 kg $\mathrm{kg}^{-1} \mathrm{tre}^{-1}$ year $^{-1}$ is applied to the Tommy Atkins and Haden verieties. Whereas, an NPK doses of 0.4-0.2 - 0.2.2 $\mathrm{kg}^{-1}$ tree $^{-1}$ year $^{-1}$ are recommended for plants aged from 10 - 15 years of age in North Pacific regions (Chávez-Contreras et al., 2001).

Table 2 shows the fertilizers dosage recommendation for bearing mango trees in various parts of the world where mangoes grow. 
Table 2 - Fertilization of nitrogen (N), phosphorus (P) and potassium (K) to fruit bearing trees in various countries

\begin{tabular}{lccccl}
\hline \multirow{2}{*}{ Country } & \multirow{2}{*}{$\begin{array}{c}\text { Tree age } \\
\text { (years) }\end{array}$} & \multicolumn{2}{c}{ Amounts of nutrients (g plant $^{-1}$} & Rear \\
\cline { 3 - 5 } & $20-25$ & $\mathbf{N}$ & $\mathbf{P}$ & $\mathbf{K}$ & Reference \\
\hline Pakistan & 1000 & 750 & 750 & Anees et al. (2011) \\
\hline $\begin{array}{l}\text { Northern } \\
\text { Pacific region }\end{array}$ & $10-15$ & 2800 & 900 & 1800 & Crane et al. (2009) \\
\hline India & $>10$ & 1000 & 500 & 1000 & Negi (2000) \\
\hline Mexico & $>20$ & 1000 & 500 & 1000 & Crane et al. (2009) \\
\hline $\begin{array}{l}\text { Queensland, } \\
\text { Australia }\end{array}$ & 10 & 1750 & 880 & 1650 & Sanewski (1991) \\
\hline Taiwan & $>11$ & 360 & 240 & 540 & Crane et al. (2009) \\
\hline Brazil & - & 1200 & 1500 & 2500 & Crane et al. (2009) \\
\hline
\end{tabular}

\section{Soil and mango leaf analyses}

Soil chemical analysis of mango farm and mango leaves analysis is a useful step in determining and handling the nutrients status of the mango garden. Analysis of soil samples provides information of the necessary minerals and nutrients essential for the mango plant growth and development plants within appropriate limits (Anonymous, 2007). Soil chemical analysis helps to determine the phyisochemical properties of soil, including soil $\mathrm{pH}$, electrical conductivity, organic matter content, and clay content. Cell tissue analysis of mango plant, with chemical analysis of soil from a mango orchard, is a helpful tool for measuring the variations in soil mineral properties and can influence fertilization use (Bally, 2009).

Samples from depths and locations should be collected to examine the nutrients status of soil before the establishment of mango orchard. Whereas, the sampling depth and sampling points will be different depending upon soil type and age of the tree, form the already established mango garden. In the soil with sandy texture and deep sampling is recommended $(1-1.5 \mathrm{~m})$ because nutrient may leach down, and deep sampling is required to analysis the accommodated nutrients and to prevent the over fertilization (Bally, 2009).

The leaf of mango plant should be analyzed in order to monitor and manage the nutrient requirements of the plants. Nutrient deficiency and abundance can be determined by visual leaves symptoms. The nutrient index status is often displayed by the leaves at different time for different minerals. When the mango plants have reached the full phenolic stage (the nutrient level of the leaves is very stable), the leaves sampling should be proceeded. The leaves from the plants of age of 6-8 months be plucked from different sides and canopy to avoid the variations in the analysis of results (Bally, 2009). The leaf samples should be collected from different cultivars, 
soil types and cultural practices individually. Further, the mango trees receiving nutrients and fungicides, such as follicle application, are prevented should be avoided from leaf sample collection. It is also suggested to wash the leaf samples with water to get rid of spray residues (Bally, 2009).

Young and Koo (1969) examined the nutritional status of the leaf samples of mango grown on calcareous and sandy soils. Significant differences in mineral content were found due to sampling of the presence or absence of fruit, soil type, cultivator and fruit. Leaf analysis shows that Table 3 reveals the sufficiency and deficiency of various mineral-related nutrients. In Brazil, mango orchards are often deficient boron (B) and zinc ( $\mathrm{Zn}$ ). Zinc sulfate and borax are used to treat deficiencies; however, leaf analysis decides the rate of fertilizers application (Silva et al., 2002). Pakistan's soils are basically alkaline, with repeated use of phosphatic source of fertilizers, which eventually enhances the phosphorus levels of the soil. These kinds of circumstances can alter the solubility and movement of micronutrients within the soil system and decreases the uptake of these nutrients by plants (lorio et al., 1996) and can lead to deficiencies of micronutrient in Pakistani soil (Anees et al., 2011). Basal and foliar methods of fertilizer applications are used to apply the micronutrients to plants; however, in comparison to soil application, the foliar application is considered to be 6-20 times more effective, as micronutrients are quickly available to the plants via leaves (Silberbush, 2002).

\section{Yield and nutrient contents}

Studies have been performed between nutrient concentrations and yields for several crops (Cotrim et al., 2019); nevertheless, the nutritional status of mango trees and its statistical relationship to the soil is complicated to determine owing to the higher buildup of minerals in trees and due to dispersal of minerals in the soil (Lobo et al., 2019). A system describing the diagnosis the leaf mineral analysis called Diagnosis and Recommendation Integrated System (DRIS) is used for this purpose. In DRIS, a ratio is needed for mineral concentrations, in spite of the full mineral contents to recognize the deficient mineral concentration. However, the DRIS has been used in mango orchards with a varying degree of success.

Raghupathi et al. (2004) suggested that the deficiencies of nutrients could not be identified by DRIS in separation, whereas, some of the researchers efficiency utilized this system. Wadt et al. (2007) and Raj and Rao (2006) used the DRIS system to identify the minerals which result in reduced yields of mango fruits in Brazil and India, respectively.

Xiuchong et al. (2001) examined the relationship between fruit production and nutrients status in leaf tissues of mango tree. They performed two studies at different locations in China, i.e., Shenzhen and Sunshui. They reported that with the appropriate application of $\mathrm{N}, \mathrm{P}, \mathrm{K}, \mathrm{S}$, 
and $\mathrm{Mg}$, the nutrient contents in the leaves of mango plants were in order of: $\mathrm{N}>\mathrm{Ca}>\mathrm{K}>\mathrm{P}>\mathrm{S}>\mathrm{Mg}$. After using 300 and $400 \mathrm{~g} \mathrm{~N}$ plant $^{-1}$ in mango orchard, no significant difference was found in $\mathrm{N}$ concentrations in leaf tissues. The contents of $\mathrm{P}$ in soil reached to $4.8-19.4 \mathrm{mg} \mathrm{kg}{ }^{-1}$ with the application of 0 and $125 \mathrm{~g} \mathrm{P}_{2} \mathrm{O}_{5}$ plant $^{-1}$ of $\mathrm{P}$, whereas there was no significant difference in leaf $P$ concentrations. Likewise, application of $320 \mathrm{~g} \mathrm{~K}_{2} \mathrm{O}$ plant $^{-1}$ resulted in an increase of $0.166-0.18 \% \mathrm{~K}$ in plant leaf then control. Akin, $40 \mathrm{~g} \mathrm{Mg} \mathrm{plant}^{-1}$ and $80 \mathrm{~g} \mathrm{~S}$ plant $^{-1}$ increased the contents of $\mathrm{Mg}$ and $\mathrm{S}$ by $0.04 \%$ $0.09 \%$ and $0.03 \%$ - $0.04 \%$, respectively, as compared to control. They concluded that increasing the application of nutrients directly increases the mango production, as a result of improved nutrient use efficiency. Further, Oosthuyse (1997) suggested that the application of $\mathrm{N}, \mathrm{K}$, phosphorus $\mathrm{P}, \mathrm{Zn}$ and $\mathrm{Mg}$ in mango orchards improves the size and fruits retaining ability of mango plants.

\section{Nutrients removal}

It has been established that the concentration of mobile nutrients $(\mathrm{N}$, $\mathrm{P}, \mathrm{K}$ and $\mathrm{Mg}$ ) decreases, whereas the concentration of immobile nutrients (calcium (Ca), boron (B), manganese $(\mathrm{Mn})$ and sulfur $(\mathrm{S})$ ) increase with the age of mango leaf (Medeiros et al., 2004). Mango leaf taken from fruiting branches of tree generally contain the higher concentration nutrients, such as $\mathrm{N}, \mathrm{K}, \mathrm{Fe}, \mathrm{Mn}, \mathrm{Zn}, \mathrm{Ca}$, and $\mathrm{Cu}$, whereas the content of aforementioned elements decreases as the fruit grows till ripening. The contents of nutrients significantly change at fruit terminals with exception of $\mathrm{P}$ and $\mathrm{Mg}$ (Oosthuyse, 2000). Moreover, it was suggested that the preference of nutrient removal by mango tree was: $\mathrm{K}_{2} \mathrm{O}>\mathrm{N}>\mathrm{P}_{2} \mathrm{O}_{5}>\mathrm{Ca}>\mathrm{Mg}>\mathrm{S}$ (Xiuchong et al., 2001). Moreover, it was reported that the nutrient removal capability of the mango tree varies with the obtained yield.

\section{Impact of various fertilizers on production and quality of mango fruit}

\section{Role of nitrogen}

Nitrogen is one of the most critical yield-reducing nutrients of all the plant's essential nutrients. Nitrogen is the basic constituent of amino acid, which are considered as building blocks of proteins and are used in formation of protoplasms (Uchida, 2000). $\mathrm{N}$ is required by the plants to accomplished various functions in plant growth, as stated below: 1. Enzymes are very important for the growth and development of plant. Enzymes are comprising of proteins, which in turn are made up of amino acids. $\mathrm{N}$ is the building blocks for amino acid production; 2. Much of chlorophyll consists of $\mathrm{N}$. Therefore, the process of photosynthesis in plants cannot be accomplished without $\mathrm{N}$; 3. $\mathrm{N}$ is an important constituent for the quantity and quality of dry matter production in plant; 4. Different vitamins within plants are composed of $\mathrm{N}$; 5. $\mathrm{N}$ is necessary for the mineralization of carbohydrates; 
6. N plays a dynamic role in the development and functioning of roots; 7. $\mathrm{N}$ plays a significant role in uptake of other essential plant nutrients.

Mango plants require an adequate supply of $\mathrm{N}$ fertilizer to accomplish various growth stages. The $\mathrm{N}$ from soil solution is absorbed by mango plant through roots in two ionic forms, i.e., ammonium $\left(\mathrm{NH}_{4}{ }^{+}\right)$ and nitrate $\left(\mathrm{NO}_{3}{ }^{-}\right)$. The effects of the $\mathrm{N}$ supply are more obvious at plant stage, the growth of floral buds, and the formation of fruit. A constant supply of $\mathrm{N}$ results in the development of shoots regularly, that effectively starts producing fruit at maturity stage (Silva, 1997). It has been reported that the application of $960 \mathrm{~g} \mathrm{~N}$ plant $^{-1}$ increased the yield of mango fruits by $86 \%$ (Nasreen et al., 2014). In another study, Sarker and Rahim (2012) used urea and cow manure (1125 g and $37.5 \mathrm{~kg}$, respectively) together and achieved almost 6-fold higher fruit production than the control. Abbas et al. (2002) observed that $\mathrm{N}$ fertilization resulted in higher amounts of soluble solids, whereas reduced the acidity in mango fruits than that of the fruits obtained from non-fertilized orchards. The impacts of $\mathrm{N}$ fertilizer on mango fruit quality are given in Table 4.

Adequate amount, time and method of $\mathrm{N}$ fertilization are of critical importance in acquiring the higher plant and fruit production, as well as improving the fruit quality. In general, reduced growth, chlorosis on older leaves, lack of flowers, and early maturity are the indications for $\mathrm{N}$ deficiency in mango plants
(Uchida, 2000). The deficiency of $\mathrm{N}$ in mango plants in turn results in stunted growth, subsequently resulting in decline the quality and mango fruit production (Reshmi et al., 2018). On contrary, the sufficiency of $\mathrm{N}$ in mango trees can lead to excessive vegetative growth, inappropriate flower differentiation, and reduced fruit yield with lower quality. Furthermore, N sufficiency in mango plants develops lush green leaves, subsequently attracting pests and increasing the risk of disease development. Magwaza and Kruger (2005) concluded that the unnecessary $\mathrm{N}$ fertilization may damage the canopy of mango tree in the postharvest period. Njuguna (2017) stated that $>1.2 \% \mathrm{~N}$ in mango leaf results in the development of greenish spots on mango fruits. Hence, the balanced utilization of $\mathrm{N}$ fertilizer is of significant importance for achieving higher fruit production with improved quality.

\section{Role of phosphorus}

Phosphorus possesses a much greater effect on the natural and agroecosystem than the other plant minerals (Brady and Wile, 2002). It has been estimated that the application of $\mathrm{P}$ in crop production has resulted in $30-50 \%$ increment in global food production, as compared to the food production in 1950 (Higgs, 2000). $P$ is considered an integral part of several plant molecules, which are responsible for photosynthesis and respiration, cell division, and growth. 


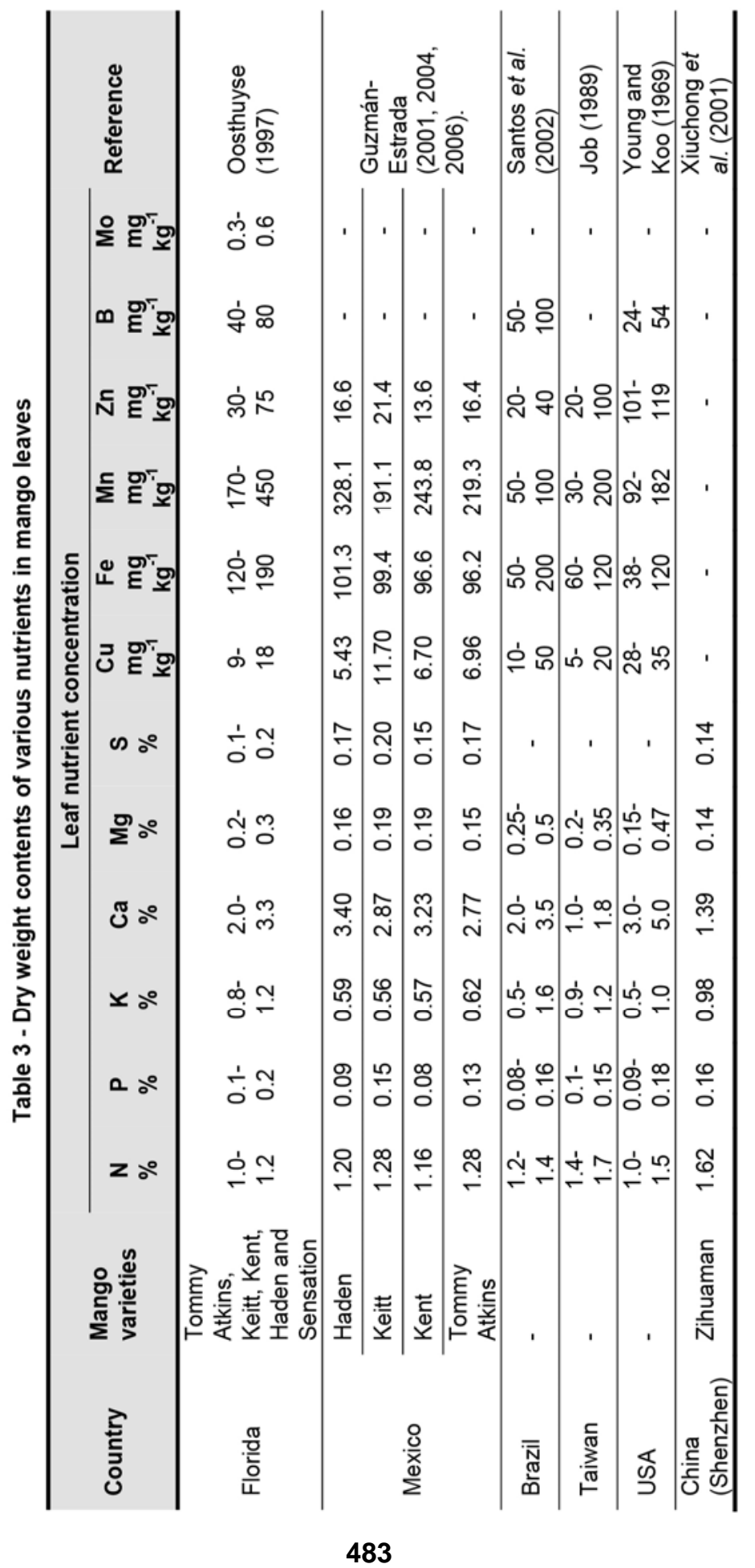


Moreover, the functioning of phospholipids, nucleotides, as well as other metabolic molecules need the presence of $\mathrm{P}$ (Salisbury and Ross, 1992). An important role of $\mathrm{P}$ application has been identified in fruit maturing, leaf elongation, and root development (Bally, 2009). Two ionic forms of $\mathrm{P}$, i.e., primary orthophosphate ion $\left(\mathrm{H}_{2} \mathrm{OP}_{4}^{-}\right)$and secondary orthophosphate $\left(\mathrm{HPO}_{4}{ }^{2-}\right)$, are available in the soil solution for plant uptake. The speciation of $\mathrm{P}$ ionic forms in the soil solution is largely dependent on soil $\mathrm{pH}$. It has been established that the level of $\mathrm{pH}$ above 7 favor the occurrence of $\mathrm{HPO}_{4}{ }^{2-}$, whereas the soil $\mathrm{pH}$ below 7 favor the presence of $\mathrm{H}_{2} \mathrm{OP}_{4}^{-}$. The extremely higher as well as lower soil $\mathrm{pH}$ levels are usually considered undesired, as they result in result in reduce $P$ availability to the plants.

Table 4 - Variations in quality of mango fruits under the application of nitrogen fertilizer

\begin{tabular}{cllll}
\hline $\begin{array}{l}\text { Sr. } \\
\text { no. }\end{array}$ & Parameters & $\begin{array}{l}\text { Reported } \\
\text { positive effect }\end{array}$ & $\begin{array}{l}\text { Reported } \\
\text { negative effect }\end{array}$ & No effect \\
\hline 1 & $\begin{array}{l}\text { Total soluble } \\
\text { solids }\end{array}$ & - & - & $\begin{array}{l}\text { Nguyen et al. } \\
(2004)\end{array}$ \\
\hline 2 & Titratable acidity & - & - & $\begin{array}{l}\text { Nguyen et al. } \\
(2004)\end{array}$ \\
\hline 3 & $\begin{array}{l}\text { Anthracnose } \\
\text { incidence }\end{array}$ & $\begin{array}{l}\text { Nguyen et al. } \\
(2004)\end{array}$ & - & - \\
\hline 4 & $\begin{array}{l}\text { Internal } \\
\text { disorders }\end{array}$ & - & $\begin{array}{l}\text { Assis et al. } \\
(2004)\end{array}$ & - \\
\hline 5 & Lenticel damage & $\begin{array}{l}\text { Magwaza and } \\
\text { Kruger (2005) }\end{array}$ & - & - \\
\hline 6 & Mango fruit color & & $\begin{array}{l}\text { Young et al. } \\
(1962)\end{array}$ & \\
\hline
\end{tabular}

At higher soil $\mathrm{pH}$ levels, $\mathrm{P}$ may combine with $\mathrm{Ca}$ and produce calcium phosphate, whereas at lower soil $\mathrm{pH}$ levels, $\mathrm{P}$ may bound with $\mathrm{Al}, \mathrm{Mn}$ and $\mathrm{Fe}$, consequently making $\mathrm{P}$ unavailable to plants. Therefore, an optimum $\mathrm{P}$ availability occurs at $\mathrm{pH}$ of 6-7. Generally, the P bounded onto clay dissolved into the water, where plants roots can absorb it. In addition, $\mathrm{HPO}_{4}{ }^{2-}$ is more easily absorbed by the plant roots than $\mathrm{H}_{2} \mathrm{OP}_{4}^{-}$. The $\mathrm{P}$ is translocated from roots to other parts of plants in form of organic phosphate. It has been reported that phosphate ions are mobile can easily be translocated from older tissues to growth points in mango trees (Bally, 2009). That is the reason that the deficiency symptoms of $\mathrm{P}$ are seen on old leaves. Singh and Saxena (1994) suggested that these symptoms include browning of the leaves accompanied with mild necrosis, tip necrosis and stem death. However, $\mathrm{P}$ deficiency is uncommon in mango plants. Moreover, bark and roots of mango plants contain more $\mathrm{P}$ than its 
leaves (Vuuren and Stassen, 1997). Medeiros et al. (2004) observed higher $\mathrm{P}$ contents in plants during vegetative stage, than that of fruiting stage. Stassen et al. (1999) reported that inadequate supply of $\mathrm{P}$ to mango plants may results in shorter roots, reduced growth and lower fruit production. In general, $\mathrm{P}$ is positively correlated with the other macronutrients, such as $\mathrm{N}, \mathrm{K}$, and $\mathrm{Mg}$ (Fageria, 2009). Therefore, an integrated application of fertilizers may result in higher plant growth and fruit production.

\section{Role of potassium}

Potassium it plays a major role in enzyme activation, photosynthesis, respiration and starch formation (Marshner, 1995). The $\mathrm{K}$ is required for cell growth and epidermal cell walls thickness, which enabling them to resist against insects/pests and pathogens attack. $\mathrm{K}$ regulates the water levels inside the plants via controlling stomatal activities (Salisbury and Ross, 1992). It has been estimated that about $90-98 \%$ of $\mathrm{K}$ is present in the form of insoluble crystalline minerals, and is not available to plants. The ionic form of $\mathrm{K}$ which is $\mathrm{K}^{+}$occurs in soil solution and becomes available to plants (Gourley, 1999). However, due to competition with other cations, the availability of $\mathrm{K}$ varies with soil conditions. For instance, Madonsela (2019) stated that higher amounts of $\mathrm{Ca}$ and $\mathrm{Mg}$ in soil resulted in reduced $\mathrm{K}^{+}$availability to plants, owing to higher competition for the exchange sites. Besides, various other factors are also responsible for the availability of $\mathrm{K}$ to plants. $\mathrm{K}$ is transported through diffusion process from soil to the roots; however, the diffusion process is influenced by various aspects, such as moisture content, temperature, path tortuosity, and $\mathrm{K}^{+}$diffusion coefficient. It has been reported that $\mathrm{K}^{+}$is usually translocated towards younger leaves from old leaves and, therefore, roots, bark, leaves, and fruits of mango plants contain higher amounts of $\mathrm{K}$ (Vuuren and Stassen, 1997). Moreover, $\mathrm{K}$ usually remains higher mango plants during vegetative flushing time, as compared to time of flowering and fruiting (Medeiros et al., 2004). However, the higher concentration of $\mathrm{K}$ by the mango plants may interfere with the other nutrients, resulting in lower fruit production (Gourley, 1999).

The most commonly used $\mathrm{K}$ fertilizers for optimum mango production include muriate of potassium nitrate $\left(\mathrm{KNO}_{3}\right)$, potash (MOP), and potassium sulfate $\left(\mathrm{K}_{2} \mathrm{SO}_{4}\right)$. Among these fertilizers, $\mathrm{K}_{2} \mathrm{SO}_{4}$ is the widely accepted $\mathrm{K}$ fertilizer due to neutral $\mathrm{pH}$ effect, as mango plants are very susceptible to higher chloride (Bally, 2009). Owing to the mobile nature of $\mathrm{K}^{+}$ ions, symptoms of its deficiency are obvious in older leaves. It has been reported that the application of $\mathrm{KNO}_{3}$ at flowering stage improves flowering, as well as fruit setting and retention (Shinde et al., 2006; Saleh and El-Monem, 2003). There are 
fewer studies for exploring the effects of $\mathrm{K}$ fertilization on fruit quality (Marschner, 1995). Shinde et al. (2006) observed higher contents of fruit weight and ascorbic acid $(5.15 \%$ and $26.99 \%$, respectively), as well as color, taste and durability, whereas a reduction in spongy tissues and weight loss with $\mathrm{K}$ fertilization. $\mathrm{K}$ has also been reported for disease control in mango plants. For instance, Reuveni et al. (1998) and Oosthuyse (2000a) observed positive effects of $\mathrm{K}$ application for controlling.

\section{Role of calcium}

Calcium is abundantly found in alkaline and neutral soils as divalent cation (Fageria, 2009). Despite of its category of secondary nutrients, $\mathrm{Ca}$ is thought to be very crucial for proper plant growth (Fageria and Gheyi, 1999). Ca can be found in soil as exchangeable, soluble and nonexchangeable forms. About $65-85 \%$ of the exchange capacity of a soil is composed of loosely bounded exchangeable $\mathrm{Ca}$ (Mengel and Kirkby, 1987). Moreover, amphiboles, feldspar, carbonates, and phosphates minerals are bounded to the $\mathrm{Ca}$ within the soil, making it non-exchangeable. Generally, the contents of $\mathrm{Ca}$ are 10-folder higher than that of $\mathrm{Mg}^{2+}$ and $\mathrm{K}^{+}$ions.

Lower $\mathrm{Ca}$ fertilization, reduced uptake by plants, as well as decline translocation results in the development of $\mathrm{Ca}$ deficiency. The mango fruit setting is influences more with $\mathrm{Ca}$ deficiency as it has been observed that growing points of plants require higher amounts of $\mathrm{Ca}$ (Mengel and Kirkby, 1987; Marschner, 1995). Mass flow and root pressure are the means of transportation for the $\mathrm{Ca}$ from soil to roots. Nevertheless, the mechanism of root pressure to transport $\mathrm{Ca}$ in mango is not studied well (Bally, 2009). Moreover, indole acetic acid, that is produced in root apex, helps in $\mathrm{Ca}$ translocation within the plant (Ho and Adams, 1989; Banuelos et al., 1987).

Calcium deficiency is manifested in young and growing leaves first owing to its mobile nature within the plants. Therefore, the symptoms of $\mathrm{Ca}$ deficiency are obvious as membrane degeneration associated with fruit ripening (Fallahi et al., 1977; Bangerth, 1979). Further, the deficiency of $\mathrm{Ca}$ in plants directly results in cell-wall deterioration, and cell disruption (Van Eeden, 1992). The durability of mango fruits and resistance against diseases in mango plant is directly associated with $\mathrm{Ca}$ availability to plants. Various researchers have reported an improved quality of mango fruits, when $\mathrm{Ca}$ was applied through foliar spray (Hojo et al., 2009; Wahdan et al., 2011). However, the excessive amount of $\mathrm{Ca}$ contents in soil may replace the other nutrients in soil owing to competitive effects. Therefore, an integrated application of all the essential nutrients to mango plant would result in enhanced production and quality of mango fruits.

The $\mathrm{Ca}$ accumulation within the leaves of mango plants increases with 
the age of the plant (Reuter and Robinson, 1997). There is always ambiguousness in estimating the content of $\mathrm{Ca}$ in the leaves and the fruits of mango plants, as it varies from one fruit to another (Bally, 2007). This could be due to variations in the location of vascular tissues and translocation of $\mathrm{Ca}$ in the tissues
(Shorter and Joyce, 1998). For instance, Bally (2007) concluded that the $\mathrm{Ca}$ concentrations varied within the mango fruits from fruit developmental stage to ripening. The variations in mango fruit quality with $\mathrm{Ca}$ applications are demonstrated in Table 5.

Table 5 - The variations in mango fruit quality with calcium applications

\begin{tabular}{|c|c|c|c|c|}
\hline $\begin{array}{l}\text { Sr. } \\
\text { no. }\end{array}$ & Parameters & $\begin{array}{l}\text { Reported positive } \\
\text { effects }\end{array}$ & $\begin{array}{c}\text { Reported } \\
\text { negative } \\
\text { effect }\end{array}$ & No effect \\
\hline 1 & $\begin{array}{l}\text { Total soluble } \\
\text { solids }\end{array}$ & $\begin{array}{l}\text { Hojo et al. (2009); Rani } \\
\text { and Brahmachari (2003) }\end{array}$ & - & - \\
\hline 2 & Fruit colour & - & - & - \\
\hline 3 & $\begin{array}{l}\text { Titratable } \\
\text { acidity }\end{array}$ & $\begin{array}{l}\text { Wahdan et al. (2011); } \\
\text { Assis et al. (2004) }\end{array}$ & - & - \\
\hline 4 & Fruit mass & $\begin{array}{l}\text { Wahdan et al. (2011); } \\
\text { Hojo et al. (2009) }\end{array}$ & - & - \\
\hline 5 & Fruit firmness & $\begin{array}{l}\text { Wahdan et al. (2011); } \\
\text { Rani and Brahmachari } \\
\text { (2003); Evangelista et al. } \\
\text { (2000, 2002); Hojo et al. } \\
(2009)\end{array}$ & - & $\begin{array}{l}\text { Silva and Menezes } \\
\text { (2001); Sampaio et al. } \\
\text { (1999) }\end{array}$ \\
\hline 6 & $\begin{array}{l}\text { External } \\
\text { appearance of } \\
\text { the fruit } \\
\end{array}$ & $\begin{array}{l}\text { Freire-Junior and Chitarra } \\
\text { (1999) }\end{array}$ & - & 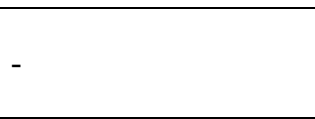 \\
\hline 7 & $\begin{array}{l}\text { Internal } \\
\text { disorders }\end{array}$ & Assis et al. (2004) & $\begin{array}{c}\text { Van Eeden } \\
\text { (1992) }\end{array}$ & $\begin{array}{l}\text { Hojo et al. (2009); } \\
\text { Silva and Menezes } \\
\text { (2001); Freire-Junior } \\
\text { and Chitarra (1999); } \\
\text { Sampaio et al. (1999) }\end{array}$ \\
\hline
\end{tabular}

\section{Role of magnesium}

Magnesium is the second most dominant cation in the soil and is an essential macronutrient for a successful growth of plant. $\mathrm{Mg}^{2+}$ is an important component of enzymes involved in transport of $\mathrm{P}$, it activates various enzymes, produces green color, and is involved in carbohydrate metabolism (Yan and Ho, 2018). Mango plants require adequate supply of $\mathrm{Mg}$ for higher fruit production. Similar to the $\mathrm{Ca}$ deficiency, the deficiency of $\mathrm{Mg}$ is generally seen in acidic soils (Fageria and Souza, 1991). The contents of $\mathrm{Mg}^{2+}$ in the soil varies greatly according to weathering of the soil and the parent material. The $\mathrm{Mg}^{2+}$ requirements for optimum growth are lower than $\mathrm{Ca}$ and varies with varieties, species, type of soil, and crop type (Fageria et al., 
1997). Various factors are responsible for affecting the $\mathrm{Mg}^{2+}$ availability to mango plants such as, concentration of $\mathrm{Mg}^{2+}$, the $\mathrm{Mg}^{2+}$ saturation, soil physiochemical properties, soil texture and type, and mango variety. Furthermore, the concentrations of $\mathrm{Na}$ and $\mathrm{K}$ ions in the soil reduces the availability of $\mathrm{Mg}^{2+}$ ions to mango plants owing to competitive effect (Aitken and Scott, 1999). Alike, higher amounts of other ions such as $\mathrm{NH}_{4}^{+}, \mathrm{Mn}^{2+}, \mathrm{Ca}^{2+}$ and $\mathrm{Al}_{3}{ }^{+}$in the soil, compete with $\mathrm{Mg}^{2+}$ as well (Yan and Ho, 2018). Various studies have demonstrated that the application of $\mathrm{Mg}^{2+}$ to mango plants resulted in enhanced plant growth, fruit yield, and quality (Xiuchong et al., 2001). The impacts of $\mathrm{Mg}^{2+}$ fertilization for improving mango fruit quality is presented in Table 6.
It has been seen that $\mathrm{Mg}^{2+}$ is a mobile nutrient and it is translocated within the plant body in the form of $\mathrm{Mg}^{2+}$ ion. Hence, the deficiency of $\mathrm{Mg}^{2+}$ appears in older leaves initially. The symptoms of $\mathrm{Mg}^{2+}$ deficiency can be recognized as yellowish leaves and necrosis in leaf lamina. The yellow leaves round and color, while the leaf veins remain green. The deficiency $\mathrm{Mg}^{2+}$ has widely been seen in sandy soils, where leaching is more. Further, the soil with lower cation exchange capacities, and higher $\mathrm{K}$ fertilization are prone to $\mathrm{Mg}^{2+}$ deficiency (Stassen et al., 1999). Therefore, appropriate use of integrated fertilization schemes including $\mathrm{Mg}^{2+}$ along with weed, diseases and pest control measures could result in enhances mango fruit production with enhanced quality.

Table 6 - The impacts of magnesium fertilization for improving mango fruit quality

\begin{tabular}{llccc}
\hline $\begin{array}{l}\text { Sr. } \\
\text { no. }\end{array}$ & Parameters & $\begin{array}{c}\text { Reported positive } \\
\text { effect }\end{array}$ & $\begin{array}{c}\text { Reported negative } \\
\text { effect }\end{array}$ & $\begin{array}{c}\text { No } \\
\text { effect }\end{array}$ \\
\hline 1 & $\begin{array}{l}\text { Total soluble } \\
\text { solids }\end{array}$ & - & - & - \\
\hline 2 & Titratable acidity & - & - & - \\
\hline 3 & Fruit mass & Xiuchong et al. (2001) & - & - \\
\hline 4 & Internal disorders & - & Assis et al. (2004) & - \\
\hline
\end{tabular}

\section{Role of boron}

Boron (B) is among the essential micronutrients for plant development and growth. However, the excessive B supply could develop toxicity. The function of $B$ in plant physiology is not studies well, nonetheless, its role in cell wall formation is well established (Zia et al., 2006; Hu and Brown, 1994). The formation of pollen, retention of flowers, protein synthesis, as well as transport of sugar in mango plants is controlled by B (Hansch and Mendel, 2009; Gupta et al., 1985). Hence, a continuous supply of B is essential for successful fruit setting in mango plants (Raja et al., 2005). If not supplied in appropriate amount, inner and outer cork of mango plants may hinder and mango fruit may get cracks due to inadequate supply of B (Zia et al., 2006). According to an 
estimate, the soils of more than 80 countries, including Pakistan, Thailand, India, Brazil, Africa, South and Central America, and Australia are suffering from B deficiency (Singh et al., 2005; Naik and Bhatt, 2017; Zia et al., 2006; Fageria et al., 2002; Oldoni et al., 2018). Zia et al. (2006) reported the deficiency of $B$ soil of Pakistan, whereas $\mathrm{Xu}$ et al. (2001) reported 33 million hectares of arable land in China are B deficient. The main reason for widespread $\mathrm{B}$ deficiency could be to the insoluble mineral source of B (tourmaline) (Gupta et al., 1985). The overall effects of B application to mango fruit quality are presented in Table 7 .

The preferable forms of $\mathrm{B}$ for plants uptake are identified as boric acid $\left(\mathrm{H}_{3} \mathrm{BO}_{3}\right.$ or $\mathrm{B}(\mathrm{OH})_{3}$ (Marshner, 1995). It has been reported that $B$ moves within soil via mass flow; however, the involvement of active and passive method of $B$ transportation in soil has not been studied well (Mattiello et al., 2009.). Soil physicochemical characteristics $(\mathrm{pH}), \mathrm{B}$ concentration is soil, type and texture of soil, specie, and soil moistures contents significantly affect the $\mathrm{B}$ availability to mango plants (Welch et al., 1991). In addition, B retention in coarse soil is lower due to higher leaching. It is worth mentioning that, unlike other nutrients, the B uptake from soil to mango plants increases with rise in temperature.

The application of $\mathrm{B}$ to mango orchard has been seen to improve the fruit production and quality for various cultivars of mango (Galli et al.,
2013). Likewise, Anees et al. (2011), Barbosa et al. (2016), Baiea et al. (2015) and Ali et al. (2017) observed an enhanced quality and production of mango under B fertilization. Moreover, Raja et al. (2005) suggested that application of B with foliar spray was more effective than soil application. Thus, integrated application of foliar $\mathrm{B}$ in the form of $\mathrm{H}_{3} \mathrm{BO}_{3}, \mathrm{FeSO}_{4}$ and $\mathrm{ZnSO}_{4}$ could significantly improve the mango yield and production with enhanced fruit quality (Anees et al., 2011; Bhatt et al., 2012).

The deficiency of $\mathrm{B}$ in mango plants can be recognized by less flowering, less pollination and fewer fruit setting. This could be due to irregular cell division resulting in curved leaves, fruit pitting, as well as bent margins and lumina (Siddiq et al., 2017; Crane et al., 2009). As a result, the stems start to black losing apical dominance, consequently resulting in stunted growth. Moreover, the higher levels of $\mathrm{N}$ and $\mathrm{Ca}$ contents in soil result in B deficiency as well (Raja etal., 2005; Ram et al., 1989). Marshner (1995) stated that here is a marginal difference between B deficiency and toxicity. Excessive application of B fertilizer may develop a B toxicity in soils. Black spots on the edges of the leaves and necrosis on the margins of leaves are the indications of B toxicity (Crane et al., 2009). Therefore, in case of the appearance of B toxicity symptoms, the surplus B must be leached down from root zone for persistent mango plant growth. Alike, a deficiency of $B$ can also be compensated with appropriate 
application of B fertilizer in order to production and quality (Saran and achieve optimum mango fruit

Ratan, 2011; Sharma and Singh 2009).

Table 7 - The effects of boron fertilization on production and quality of mango fruit

\begin{tabular}{clccc}
\hline $\begin{array}{c}\text { Sr. } \\
\text { no. }\end{array}$ & Parameters & Reported positive effect & $\begin{array}{c}\text { Reported a } \\
\text { negative effect }\end{array}$ & $\begin{array}{c}\text { No } \\
\text { effect }\end{array}$ \\
\hline 1 & $\begin{array}{l}\text { Total soluble } \\
\text { solids }\end{array}$ & $\begin{array}{l}\text { Oldoni et al. (2018); Anees et } \\
\text { al. (2011); Bhatt et al. (2012) }\end{array}$ & - & - \\
\hline 2 & $\begin{array}{l}\text { Titratable } \\
\text { acidity }\end{array}$ & $\begin{array}{l}\text { Oldoni et al. (2018); Anees et } \\
\text { al. (2011); Bhatt et al. (2012) }\end{array}$ & - & - \\
\hline 3 & Fruit mass & $\begin{array}{c}\text { Bhatt et al. (2012); } \\
\text { Raja and Kumar (2003); Oldoni } \\
\text { et al. (2018) }\end{array}$ & - & - \\
\hline 4 & $\begin{array}{l}\text { Internal } \\
\text { disorders }\end{array}$ & $\begin{array}{c}\text { Saran and Ratan (2011); } \\
\text { Sharma and Singh (2009) }\end{array}$ & - & - \\
\hline 5 & Total sugar & Bhatt et al. (2012) & - & - \\
\hline 6 & $\begin{array}{l}\text { Ascorbic } \\
\text { acid }\end{array}$ & $\begin{array}{c}\text { Baiea et al. (2015); Anees et al. } \\
(2011) ; \text { Oldoni et al. (2018) }\end{array}$ & - & - \\
\hline
\end{tabular}

\section{Role of zinc}

Zinc is an essential micronutrient for the successful growth and production of the plant owing to its significant contribution in the synthesis of chlorophyll, proteins, hormones and in conducting the process of photosynthesis (Weir and Chresswell, 1995). Plants absorb Zn from the soil solution in in ionic form $\left(\mathrm{Zn}^{2+}\right)$, and then translocate it to other parts of the plant. However, the translocated $\mathrm{Zn}$ does not become available easily to other tissues of the plant. In addition, due to deep rooting system of mango, it is harder to apply $\mathrm{Zn}$ in root zone. However, the chelating agents produced from roots of mango plants may help in $\mathrm{Zn}$ translocation (Stevenson, 1986). Therefore, foliar application of $\mathrm{Zn}$ because it is considered as more efficient, as plant can absorb $\mathrm{Zn}$ through leaves as well. Further, foliar $\mathrm{Zn}$ application is preferred as $\mathrm{Zn}$ is immobile in soil (Tisdale et al., 1985).
Exogenous $\mathrm{Zn}$ application to mango plants improves the quality and production of mango fruits (Table 8).

The deficiency of $\mathrm{Zn}$ in various soils have been reported globally. The development of leaflets and shortening of internode spacing on mango plants could be a sign of $\mathrm{Zn}$ deficiency (Dilly et al., 1997; Agarwala et al., 1988; Marshner, 1995). The Zn availability to plants is directly linked with $\mathrm{pH}$ of the soil. Further, the higher calcite $\left(\mathrm{CaCO}_{3}\right)$ contents in soil reduces the availability of $\mathrm{Zn}$ to plants owing to higher $\mathrm{pH}$ levels (Trehan and Sekhon, 1977). Similar, it was reported that $\mathrm{Zn}$ availability to plants is significantly influenced by the soil $\mathrm{pH}$ (Anderson and Christensen, 1988). Therefore, widespread $\mathrm{Zn}$ deficiency is reported in the soils of Pakistan and India owing to alkaline soils with higher calcite contents (Naik and Bhatt, 2017; Zia et al., 2006). Besides, the availability of $\mathrm{Zn}$ to plant is also influenced by the 
contents of clay, organic matter, calcite contents, iron oxide, and aluminum oxide. Moreover, higher concentrations of $\mathrm{P}$ in the soil may also reduce the availability of $\mathrm{Zn}$ to the soil (Robson and Pitman, 1983). Fageria and Gheyi (1999) observed $\mathrm{Zn}$ deficiency in soil exhibiting $P$ toxicity and vice versa. The improved fruit production and quality has been seen with the application of $\mathrm{Zn}$ by various researchers. For instance, Singh and Rajput (1977) reported that the application of $\mathrm{ZnSO}_{4}$ application resulted in higher ascorbic, fruit sugar, and production of mango fruit. Likewise, an improvement in fruit quality and setting was reported by Daulta et al. (1981) with foliar application of $\mathrm{Zn}$ fertilization.

Table 8 - Exogenous zinc application on fruit quality and production of mango fruits

\begin{tabular}{llclc}
\hline $\begin{array}{l}\text { Sr. } \\
\text { no. }\end{array}$ & Parameters & Reported positive effect & $\begin{array}{c}\text { Reported } \\
\text { negative effect }\end{array}$ & $\begin{array}{c}\text { No } \\
\text { effect }\end{array}$ \\
\hline 1 & $\begin{array}{l}\text { Total } \\
\text { soluble } \\
\text { solids }\end{array}$ & $\begin{array}{c}\text { Panwar et al. (2007); Singh and } \\
\text { Rajput (1977); Inees et al. (2011); } \\
\text { Bhatt et al. (2012) }\end{array}$ & - & - \\
\hline 2 & $\begin{array}{l}\text { Titratable } \\
\text { acidity }\end{array}$ & $\begin{array}{c}\text { Inees et al. (2011); Singh and Rajput } \\
\text { (1977); Bhatt et al. (2012) }\end{array}$ & - & - \\
\hline & Fruit mass & $\begin{array}{c}\text { Raja and Kumar (2003); Singh and } \\
\text { Rajput (1977); Bhatt et al. (2012); } \\
\text { Inees et al. (2011) }\end{array}$ & - & - \\
\hline 4 & Total sugar & Panwar et al. (2007) & - & - \\
\hline
\end{tabular}

In another study, it has been observed that $1 \%$ foliar application of $\mathrm{ZnSO}_{4}$ resulted in enhanced vitamin A and sugars with lower acidity (Kumar and Kumar, 1989). Likewise, it was reported that $1 \%$ foliar spray of $\mathrm{ZnSO}_{4}$ was sufficient to prevent optimum plant growth (Littlemore et al., 1991).

\section{Role of other micronutrients}

Beside afore mentioned micronutrient, $\mathrm{Fe}, \mathrm{Cu}$ and $\mathrm{Mn}$ are also essential for optimum plant growth. Therefore, appropriate application of all these nutrients is necessary for higher mango fruit production and deficiency of either one or more than one micronutrient would lead to reduced plant growth and fruit production (Schaefer et al., 1988).
The reduction of sulfates and nitrates, process of photosynthesis and assimilation of $\mathrm{N}_{2}$ is linked with $\mathrm{Fe}$; therefore, $\mathrm{Fe}$ management in mango plants is of critical importance. However, Fe deficiency in soils is widespread globally in mango orchards, despite of its abundance in most of the soils (Zia et al., 2006; Schmidt, 1999). It is due to the fact that $\mathrm{Fe}$ availability is directly influenced by the soil $\mathrm{pH}$. One unit increment in soil $\mathrm{pH}$ results in 1000 times reduction in $\mathrm{Fe}$ solubility (Lindsay, 1979). Hence, proper $\mathrm{Fe}$ fertilizer management is complicated in calcareous soils. Due to higher $\mathrm{pH}$ of calcareous soils (7.5-8.5), only a small proportion of the applied Fe becomes available to the plants (Lindsay, 
1991). Plants can absorb Fe either in the form of $\mathrm{Fe}^{2+}$ and/or $\mathrm{Fe}^{3+}$; nevertheless, $\mathrm{Fe}^{2+}$ has been shown to be more soluble than $\mathrm{Fe}^{3+}$. Moreover, in aerobic condition, $\mathrm{Fe}^{2+}$ can be oxidized to produce $\mathrm{Fe}^{3+}$, which is not accessible to plants, whereas, through reduction process $\mathrm{Fe}^{3+}$, can be transformed to $\mathrm{Fe}^{2+}$ enhancing the availability of $\mathrm{Fe}$ to plants (Salisbury and Ross, 1992). However, the process of reducing $\mathrm{Fe}^{3+}$ to $\mathrm{Fe}^{2+}$ is controlled by the soil $\mathrm{pH}$. Ligands obtained from plants can be develop chelates $\mathrm{Fe}^{3+}$ making them available for plants. Furthermore, the efficiency of $\mathrm{Fe}$ can be enhanced substantially through foliar application of Fe than that of soil application (Bhatt et al., 2012; Anees et al., 2011).

The crucial role of $\mathrm{Mn}$ in the redox reaction, enzyme activation, decarboxylation and hydrolytic and reactions has been established (Bally, 2009). Additionally, the photosynthetic process, as well as formation of lipids, proteins and carbohydrates is linked with adequate levels of $\mathrm{Mn}$ in plants (Marchner, 1995). Plants can uptake $\mathrm{Mn}$ in the form of $\mathrm{Mn}^{2+}$, which is generally bounded to the organic matter and soil colloids (Bally, 2009). The $\mathrm{MnO}_{2}$ is transformed to $\mathrm{Mn}^{2+}$ through reduction in aerobic conditions, under lower $\mathrm{pH}$, while the microbial oxidation may occur in higher $\mathrm{pH}$. Therefore, both oxidation and reduction processes take place simultaneously in the soil system controlling the availability of $\mathrm{Mn}$ to the plants (Peverill et al., 1999). The deficiency of $\mathrm{Mn}$ in mango plants can be evidenced through the development of necrosis at leaf tips (Mohamed, 2017). The possible impacts of $\mathrm{Mn}$ application on the mango fruits quality have not been investigated well (Bally, 2009). Therefore, appropriate quantities of micronutrients must be applied on right time using right application method to achieve the optimum mango fruit production with improved quality and nutrition.

\section{Future directions}

In order to understand the factors responsible for reducing the quality, growth and production of mangoes, it is necessary to constantly research and examine different factors in several different ecological zones. Modern and smart technologies can recognize the factors that decrease the mango production, including mineral nutrients, specifically micronutrients, which are not only responsible to reduce the quality of mango fruit, but also to reduce productivity. Steps are needed to be taken to make better mango production and quality of fruits through the integrated and balanced nutrient management. Mango producers, scientists, horticulture specialist and extension workforces should work in joint ventures to share the knowledge. To predict and diagnose phenological needs at different ecological regions and times, there is a need to combine biotic and abiotic factors to increase productivity. Increasing research and horticulture requires the incorporation of new models, software and friendly 
programs into the light production and plant growth phases. The importance of supporting organic farming techniques in conjunction with nature and science cannot be deprived. Finally, there is an urgent need to sustain and build a resilient bridge between mango producers, technologists and researchers in order to increase mango production and ensure quality production.

\section{CONCLUSIONS}

Due to nutritional values with a nice aroma, taste, flavor and health, mango is recognized as "king of fruits" in South Asia. Although, mango trees can be cultivated on a vast range of soil characteristics nonetheless, tree mineral status should be measured by repeating leaf and soil chemical analysis. True understanding was gained from the nutritional effects of the explanations rather than from the results on the qualitative parameters of the mango fruit. The yield and quality of the mango fruit can be improved to a great extent in result of the applied mineral nutrients by describing their role in phenology. Continuous monitoring of the mango tree helps to plan a nutritional program for mangoes. It is essential to monitor the mineral status at different growth stages. The growth and development of the mango industry requires the development and commitment of a fast, economical, easily accessible and ecological mineral nutrition program.

\section{REFERENCES}

Abbas, H.R.A.S.G., Hafiz, I.A., Ahmad, S. \& Khan, M. (2002). Nitrogen concentration at various growth stages of mango and effect of calcium carbide on fruit quality. Asian J. Plant Sci., 1(2): 164-166, DOI: 10.3923/ajps.2002.164.166

Agarwala, S.C., Nautiyal, B.D., Chatterjee, C. \& Sharma, C.P. (1988). Manganese, zinc and boron deficiency in mango. Sci.Hortic., 35(1-2): 99-107, DOI: 10.1016/03044238(88)90041-6

Aitken, R.L. \& Scott, B.J. (1999). Magnesium. In: Peverill, K.I., Sparrow, L.A., Reuter, D.J. (Eds), Soil analysis: an interpretation manual. Commonwealth Scientific and Industrial Research Organization (CSIRO), Melbourne, Australia, pp. 255-262.

Ali, M.S., Elhamahmy, M.A. \& El-Shiekh, A.F. (2017). Mango trees productivity and quality as affected by boron and putrescine. Sci.Hortic., 216: 248-255, DOI: 10.1016/j.scien ta.2017.01.026

Anderson, P.R. \& Christensen, T.H. (1988). Distribution coefficient of $\mathrm{Cd}$, $\mathrm{Co}, \mathrm{Ni}$, and $\mathrm{Zn}$ in soils. J. Soil Sci., 39(1): 15-22, DOI: 10.1111/j.13652389.1988.tb01190.x

Andrade, L.R.M. de (2004). Corretivos e fertilizantes para culturas perenes e semiperenes. In: Sousa, D.M.G. and Lobato, E. (Eds.), Cerrado, Correcao do Solo e Adubacao. Embrapa Informação Tecnológica, Brasilia, Brazil, pp. 317-366.

Anees, M., Tahir, F.M., Shahzad, J. \& Mahmood, $N$ (2011). Effect of foliar application of micronutrients on the quality of mango (Mangifera indica) Cv. Dusehri Fruit. Mycopath, 9(1): 25-28.

Anonymous (2007). A guide to soil sampling. spectrum analytic. Available at: http://www.spectruma nalytic.com/support/library/ff/soil_sa 
mpling instructons.htm (accessed $11^{\text {th }}$ February 2017)

Assis, J.S. de, Silva, D.J. \& de Morais, P.L.D. (2004). Equilíbrio nutricional e distúrbios fisiológicos em manga 'Tommy Atkins'. Rev.Bras.Frutic., Jaboticabal, 26(2): 326-329, DOI: 10.1590/S010029452004000200034

Baiea, M.H.M., El-Badawy, H.E.M. \& ElGioushy, S.F. (2015). Effect of potassium, zinc and boron on growth, yield and fruit quality of Keitt mango trees. Res.J.Pharm.Biol. Chem.Sci., 6(4): 800-812.

Bally, I.S.E. (2006). Mangifera indica L. (mango). In: Species Profiles for Pacific Island Agroforestry (Ed. C.R. Elevitch), pp. 1-25. Permanent Agriculture Resources (PAR), Hōlualoa, Hawaii. (http://www.traditi onaltree.org) (accessed $10^{\text {th }}$ February 2020)

Bally, I.S.E. (2007). The effect of preharvest nutrition and crop load on fruit quality and postharvest disease in mango (Mangifera indica L.). PhD dissertation, University of Queensland, Brisbane, Australia.

Bally, I.S.E. (2009). Crop production: mineral nutrition. In: The Mango, $2^{\text {nd }}$ Edition: Botany, Production and Uses (Ed. R.E. Litz). CAB International, UK.

Bangerth, F. (1979). Calcium-related physiological disorders of plants. Ann.Rev.Phytopathol., 17: 97-122, DOI: 10.1146/annurev.py.17.09017 9.000525

Banuelos, G.S., Bangerth, F. \& Marschner, H. (1987). Relationship between polar basipetal auxin transport and acropetal $\mathrm{Ca}^{2+}$ transport in tomato fruit. Physiol.Plant., 71, 321-327, DOI: 10.1111/j.1399-3054.1987.tb04350.x

Barbosa, L.F.S., Cavalcante, I.H.L. \& Lima, A.M.N. (2016). Desordem fisiológica e produtividade de mangueira cv. Palmer associada à nutrição de boro. Rev.Bras.Frutic.,
Jaboticabal, $\quad 38(1): \quad 1-9, \quad$ DOI: 10.1590/0100-2945-273/14

Bhatt, A., Mishra, N.K., Mishra D.S. \& Singh, C.P. (2012). Foliar application of potassium, calcium, zinc and boron enhanced yield, quality and shelf life of mango. Hort Flora Res. Spectrum, 1(4): 300-305.

Bitange, N.M., Chemining'wa, G.N., Ambuko, J. \& Owino, W.O. (2020). Can calcium sprays alleviate jelly seed in mango fruits? J.Agr. Rural Develop.Trop.Subtrop., 121(1): 3542, DOI: 10.17170/kobra-202002 281032

Brady, N.C. \& Wei, R.R. (2002). The nature and properties of soils. $13^{\text {th }}$ Ed., Prentice Hall, Upper Saddle River, New Jersey.

Chávez-Contreras, X., Vega-Piña, A., Tapia-Vargas, L.M. \& MirandaSalcedo, M.A. (2001). Mango, su manejo y producción en el trópico seco de México. Libro Técnico Num. 1. Campo Experimental Valle de Apatzingán. CIRPAC, INIFAP, México, p. 108.

Choudhary, D. \& Mehta, A. (2010). Fruit crops. Jaipur, India, Oxford Book Company. www.oxfordbookcompa ny. com

Cotrim, C.E., Santos, M.R.D., Coelho, E.F. \& Silva, J.A.D. (2019). Sap flow in 'Tommy Atkins' mango trees under regulated deficit irrigation. Rev.Ambient.Água, 14(3), DOI: 10.4 136/ambi-agua.2316

Crane, J.H., Salazar-García, S., Lin, T.S., de Queiroz Pinto. A.C. \& Shü, Z.H. (2009). Crop production: management. In: The Mango, $2^{\text {nd }} E d$.: Botany, Production and Uses (Ed. R.E. Litz). CAB International, UK. Daulta, B.S., Singh, H.K. \& Chauhan, K.S. (1981). Effect of zinc and CCC sprays on flowering fruiting and physico-chemical composition of fruit in mango (Mangifera indica L.) cv. Dashehari. Haryana J.Hort.Sci., 10(3-4): 161-165.

Davenport, T.L. (2006). Pruning strategies to maximize tropical 


\section{SUSTAINABLE MANAGEMENT OF MANGO NUTRITION FOR BETTER YIELD AND QUALITY}

mango production from the time of planting to restoration of old orchards. HortSci., 41(3): 544-548, DOI: 10.21273/HORTSCI.41.3.544

Dilly, O., Romheld, V., Marschner, H. \& Chen, Y. (1997). Nutritional disorder in mango trees on calcareous soil in Israel. Acta Hortic., 448: 362-362, DOI: $10.17660 /$ ActaHortic.1997.448. 67

Dinesh, M.R. (2003). Genetical studies in mango (Mangifera indica L.). J.Appl.Hort., 5(1): 27-28.

Dirou, J.F. (2004). Mango growing. Agfact H6.1.10, $4^{\text {th }}$ Ed., NSW Centre for Tropical Horticulture, Alstonville, Australia.

Douthett, D.G. (2000). The mango: Asia's king of fruits. Southern Illinois University Carbondale, Ethnobotanical Leaflets.

Elsheery, N.I., Helaly, M.N., El-Hoseiny, H.M. \& Alam-Eldein, S.M. (2020). Zinc oxide and silicone nanoparticles to improve the resistance mechanism and annual productivity of salt-stressed mango trees. Agron., 10(4): 558, DOI: 10.3390/ag ronomy 10040558

Evangelista, R.M., Chitarra, A.B. \& Chitarra, M.I.F. (2000). Influência da aplicação pré-colheita de cálcio na textura e na atividade das enzimas poligalacturonase, pectinametilesterase e $\beta$-galactosidase de mangas 'Tommy Atkins' armazenadas sob refrigeração. Ciên.Agrotec., 24 (Edição Especial), 174-181.

Evangelista, R.M., Chitarra, A.B. \& Chitarra, M.I.F. (2002). Mudanças na ultraestrutura da parede celular de mangas 'Tommy Atkins' tratadas com cloreto de calcio na précolheita. Rev.Bras.Frutic., 24(1): 254-257, DOI: 10.1590/S0100-2945 2002000100056

Fageria, N.K. \& Souza, C.M.R. (1991). Upland rice, common bean, and cowpea response to magnesium application on an oxisol. Commun. Soil Sci. Plant Anal., 22(17-18):
1805-181, DOI: 10.1080/00103629 109368537

Fageria, N.K., Baligar, V.C. \& Jones, C.A. (1997). Growth and mineral nutrition of field crops, Marcel Dekker Inc., $2^{\text {nd }}$ Edition, New York.

Fageria, N.K. \& Gheyi, H.R. (1999). Efficient crop production. Federal University of Paraiba, Campina Grande, Brazil, 574 p.

Fageria, N.K., Baligar, V.C. \& Clark, R.B. (2002). Micronutrients in crop production. Adv.Agron., 77: 185-68, DOI: $\quad 10.1016 /$ S0065-2113(02)770 $15-6$

Fageria, N.K. (2009). The use of nutrients in crop plants. Boca Raton, FL: CRC Press.

Fallahi, E., Conway, W.S., Hickey, K.D. \& Sams, C.E. (1977). The role of calcium and nitrogen in postharvest quality and disease resistance of apples. Hort.Sci., 32(5): 831-835, DOI: 10.21273/HORTSCI.32.5.831

Fischer, G., Almanza-Merchán, P.J. \& Ramírez, F. (2012). Source-sink relationships in fruit species: a review. Rev.ColombCienc. Hortíc., 6(2): 238-253, DOI: $10.17584 /$ rcch. 2012v6i2.1980

Freire-Junior, M. \& Chitarra, A.B. (1999). Effect of calcium chloride application on mango fruit cv. Tommy Atkins hydrothermally treated. Pesqui.Agropecu.Bras., 34(5): 761769, DOI: 10.1590/S0100-204X19 99000500006

Galli, J.A., Palharini, M.C.A., Fischer, H.I., Michelotto, D.M. \& Martins, L.M.A. (2013). Produção e qualidade de frutos de diferentes cultivares de mangueira adubadas com boro. Rev.Bras.Ciênc.Agrár., Recife, 8(3): 358-363, DOI: 10.5039/agraria.v8i3a2102

Gourley, C.J.P. (1999). Potassium. In: Peverill, K.I., Sparrow, L.A., Reuter, D.J. (Eds.), Soil analysis: an interpretation manual. CSIRO Publishing, Collingwood, Vic, Melbourne, Australia, pp. 229-245. 
Gupta, U.C., Jame, Y.W., Campbell, C.A., Leyshon, A.J. \& Nicholaichuk, W. (1985). Boron toxicity and deficiency: a review. Can.J. Soil Sci., 65: 318-409, DOI: 10.4141/cjss85-044

Gurjar, T.D., Patel, N.L., Panchal, B. \& Chaudhari, D. (2015). Effect of foliar spray of micronutrients on flowering and fruiting of alphonso mango (Mangifera indica L.). The Bioscan., 10(3): 1053-1056.

Guzmán-Estrada, C. (2001). Evaluación nutrimental en los huertos comerciales de mango en el sur de Sinaloa. Horticultura Mexicana, 3, 178.

Guzmán-Estrada, C. (2004). Evaluación y determinación del abastecimiento nutrimental en mango del sur de Sinaloa. Informes Anuales 2000, 2001-2003 y 2003-2004. Campo Experimental Sur de Sinaloa, Instituto Nacional de Investigaciones Forestales, Agricolas y Pecuarias (INIFAP), Sur de Sinaloa, Mexico, $12 \mathrm{p}$.

Guzmán-Estrada, C. (2006). Nutrient supply of mango in Southern Sinaloa, Mexico. (Abstract), in: The Eighth International Mango Symposium, Sun City, Johannesburg, South Africa, 5-10 February.

Hänsch, R. \& Mendel, R.R. (2009). Physiological of mineral micronutrients $\mathrm{C} \mathrm{Cu}, \mathrm{Zn}, \mathrm{Mn}, \mathrm{Fe}, \mathrm{Ni}$, Mo, B, Cl). Curr. Opin.Plant Biol., 12(3): 259-266, DOI: 10.1016/j.pbi. 2009.05.006

Higg,s B., Johnston, A.E., Salter, J.L. \& Dawson, C.J. (2000). Some aspects of achieving sustainable phosphorus use in agriculture. J.Environ.Qual., 29: 80-87, DOI: 10.2134/jeq2000. 00472425002900010010x

Ho, L.C. \& Adams, P. (1989). Calcium deficiency - a matter of inadequate transport to rapidly growing organs. Plants Today, 2: 202-207.

Hojo, R.H., São-José, A.R., Hojo, E.T.D., Alves, J.F.T., Rebouças, T.N.H. \& Dias, N.O. (2009). Quality of
"Tommy Atkins" mangoes in post-harvest with calcium chloride spray use in the preharvest period. Rev.Bras.Frutic., 31(1): 62-70, DOI: 10.1590/S0100-294520090001000 10

Hu, H. \& Brown, P.H. (1994). Localization of boron in cell walls of squash and tobacco and its association with pectin. Plant Physiol., 105(2): 681689, DOI: 10.1104/pp.105.2.681

Iorio A.I., De-Gorgoschode, L., Rendina, A. \& Barros, M.J. (1996). Effect of phosphorous, copper and zinc addition on the phosphorus, copper and phosphorus/zinc interaction in lettuce. J. Plant Nutr., 19(3-4): 481491, DOI: 10.1080/019041696093 65137

Job, J.R. (1989). Fertilizer application rates, soil fertilities, yields and qualities of mangoes in Taiwan. Soil and fertilizer experiment report. Department of Agriculture and Forest, Taiwan Province, Taichung, pp. 201-229.

Kumar, O.V. \& Kumar, G. (1989). Effect of pre-harvest foliar sprays of zinc on post-harvest changes in the quality of mango cv. Dashehari. Acta Hortic., 231: 763-770, DOI: 10.17660/ActaHortic.1989.231.43

Lindsay, W.L. (1979). Chemical equilibria in soils. John Wiley \& Sons, New York. 449 p.

Lindsay, W.L. (1991). Inorganic equilibria affecting micronutrients in soil (pp. 89-112). In: Micronutrients in agriculture. $2^{\text {nd }}$ Ed., Mortvedt, J.J., Cox, F.R., Shuman, L.M., Welch, R.M. (Eds.). Soil Science Society of America, Madison, WI.

Littlemore, J., Winston, E.C., Howitt, C.J., O'Farrell, P. \& Wiffen, D.C. (1991). Improved methods for zinc and boron applications to mango (Mangifera indica L.) cv. Kensington Pride in the Mareeba-Dimbulah district of North Queensland. Aust.J.Exp.Agri., 31(1): 117-121, DOI: 10.1071/EA9910117 
Lobo, J.T., Cavalcante, Í.H.L., Lima, A.M.N., Vieira, Y.A.C., Modesto, P.I.R. \& da Cunha, J.G. (2019). Biostimulants on nutritional status and fruit production of mango 'Kent' in the Brazilian semiarid region. HortSci., 54(9): 1501-1508, DOI: 10.21273/HORTSCI13753-18

Maas, E.V. \& Grattan, S.R. (1999). Crop yields as affected by salinity. In: Skaggs, R.W., van Schilfgaarde, J. (Eds.), Agriculture Drainage, Vol. 38, Agronomy Monographs, Madison, WI, pp. 55-108, DOI: 10.2134/ agronmonogr38.c3

Madonsela, E.N. (2019). Defining and describing fruit quality of mango, its development and protection in fruit production. Acta Sci.Agric., 3(9): 3841, DOI: 10.31080/ASAG.2019.03. 0603

Magalhães, A.F. de J. \& Borges, A.L. (2000). Calagem e adubação. In: Matos, A.P. de (Org.) Manga produção, aspectos técnicos. Embrapa Comunicação para Transferência de Tecnologia, Brasília.

Magwaza, L. \& Kruger, F.J. (2005). Development of skin moisture and pulp nitrogen content parameters for the control of lenticel damage in Tommy Atkins and Keitt mangoes. South African Mango Grower's Association, 25: 19-22.

Marschner, H. (1995). Mineral nutrition of higher plants, $2^{\text {nd }}$ Ed., Academic Press, London.

Mattiello, E.M., Ruiz, H.A., Silva, I.R.D., Barros, N.F., Neves, J.C.L. \& Behling, M. (2009). Transporte de boro no solo e sua absorção por eucalipto. Rev.Bras. Ciênc. Solo, Viçosa, 33(5): 1281-1290, DOI: 10. 1590/S0100-06832009000500021

Medeiros, A.A., Amorim, J.R.A., Silva, D.J., Dantas, J.A. \& Guerra, A.G. (2004). Mineral composition of leaves and fruits of irrigated mango trees in Rio Grande do norte state Brazil. Acta Hortic., 645: 403-408,
DOI: $10.17660 /$ ActaHortic.2004.645. 50

Mengel, K. \& Kirkby, E.A. (1987). Principles of plant nutrition, $4^{\text {th }}$ Ed., International Potash Institute, Worblaufen-Bern, Switzerland.

Mohamed, S.M.M. (2017). Response of mango trees to application of magnetite, natural mixture compound and selenium under drip irrigation system in sandy soil (PhD. Thesis). Department of Horticulture, Ain Shams University, Egypt.

Naik, S.K. \& Bhatt, B.P. (2017). Diagnostic leaf nutrient norms and identification of yield-limiting nutrients of mango in eastern plateau and hill region of India. Commun. Soil Sci. Plant Anal., 48(13): 1574-1583, DOI: 10.1080/ 00103624.2017.1374396

Nasreen, S., Kamal, A.M., Siddiky, M.A., Rannu, R.P. \& Islam, M.S. (2014). Effect of nitrogen, phosphorus, potassium and sulphur on the yield of mango. Bangladesh J.Agric.Res., 39(4): 631-640, DOI: 10.3329/bjar. v39i4.22542

Negi, S.S. (2000). Mango production in India. Acta. Hortic., 509: 69-78, DOI: 10.17660/ActaHortic.2000.509.4

Nguyen, H., Hofman, P., Holmes, R., Bally, I., Stubbings, B. \& McConchie, R. (2004). Effect of nitrogen on the skin colour and other quality attributes of ripe 'Kensington Pride' mango (Mangifera indica L.) fruit. J.Hortic.Sci.Biotech., 79(2): 204-210, DOI: 10.1080/14620316. 2004.11511749

Njuguna, J.K. (2017). Evaluation of mango (Mangifera Indica L.) mineral nutrition on jelly seed disorder, fruit yield and quality (PhD. Thesis), University of Nairobi.

Oldoni, F.C.A., Lima, A.M.N., Cavalcante, I.H.L., de Sousa, K.S.M., Carneiro, M.A. \& de Carvalho, I.R.B. (2018). Boron fertilizing management on fruit production and quality of mango $\mathrm{cv}$. Palmer in semiarid. Rev.Bras. 
Frutic., Jaboticabal, 40(3), DOI: 10.1590/0100-29452018622

Oosthuyse, S.A. (1997). Effect of $\mathrm{KNO}_{3}$ sprays to flowering mango trees on fruit retention, fruit size, tree yield, and fruit quality. Acta Hortic., 455: 359-366, V International Mango Symposium, DOI: 10.17660/Acta Hortic.1997.455.46

Oosthuyse, S.A. (2000). Variation of leaf nutrition status in relation to fruit growth in mango. Acta Hortic., 509: 375-378, VI International Symposium on Mango, DOI: 10.17660/ActaHort ic. 2000.509 .43

Oosthuyse, S.A. (2000a). Cost reduction of powdery mildew control in mango with mono potassium phosphate. Acta Hortic., 509: 719-723, VI International Symposium on Mango, DOI: 10.17660/ActaHortic. 2000.509. 83

Panwar, R. \& Singh, C.P. (2007). Effect of pre-harvest foliar spray of micronutrients on chemical properties of mango fruit cv. Langra. Pantnagar J.Res., 5(1): 56-61.

Paull, R.E. \& Duarte, O. (2011). Mango. In: Tropical fruits, $2^{\text {nd }}$ Ed., Vol. 1. $C A B$ International, UK.

Peverill, K.I., Sparrow, L.A. \& Reuter, D.J. (Eds.) (1999). Soil analysis: an interpretation manual. CSIRO, Melbourne, Australia.

Raghupathi, H.B., Reddy, Y.T.N., Reju, M.K. \& Bhargava, B.S. (2004). Diagnosis of nutrient imbalance in mango by DRIS and PCA approaches. J. Plant Nutr., 27(7): 1131-1148, DOI: $10.1081 /$ PLN-120 038540

Raj, G.B. \& Rao, A.P. (2006). Identification of yield-limiting nutrients in mango through DRIS indices. Commun. Soil Sci. Plant. Anal., 37(11-12): 1761-1774, DOI: 10.1080/00103620600710587

Raja, E.M. \& Anil Kumar, S.C. (2003). Boron deficiency: a serious yield-limiting factor in Alphonso mango of Konkan, Maharashtra. In: Proceedings of $68^{\text {th }}$ Annual
Convention of the Indian Society of Soil Science, Kanpur, India.

Raja, M.E., Kumar, S.C.A. \& Raju, S.Y. (2005). Boron deficiency in mango (Mangifera indica L.): a cause delineation study in acidic soils of Maharashtra, India. Soil Sci. Plant Nutr., 51(5): 751-754, DOI: 10.1111/ j.1747-0765.2005.tb00106.x

Ram, S., Bist, L.D. \& Sirohi, S.C. (1989). Internal fruit necrosis of mango and its control. Acta Hortic., 231: 805813, II International Symposium on Mango, DOI: 10.17660/ActaHortic. 1989.231.48

Rani, R. \& Brahmachari, V.S. (2003). Effect of foliar application of chemicals on quality characters of mango during storage. Progress. Hortic., 35(2): 216-218.

Reshmi, R., Reshma, R., Ramesh, M. \& Rashmi, Y.C. (2018). Study of the physiochemical parameters and spatial viability of available nutrients in mango growing areas using GIS. i-Manager's Journal on Future Engineering and Technology, 13(4): 62-67, DOI: 10.26634/jfet.13.4.14436

Reuter, D.J. \& Robinson, J.B. (Eds.) (1997). Plant analysis: An Interpretation Manual, $2^{\text {nd }} \mathrm{Ed}$. Commonwealth Scientific and Industrial Research Organization (CSIRO), Melbourne, Australia.

Reuveni, M., Harpaz, M. \& Reuveni, R. (1998). Integrated control of powdery mildew on field-grown mango trees by foliar sprays of mono-potassium phosphate fertilizer, sterol inhibitor fungicides and the strobilurin Kresoxym-methyl. Eur.J. Plant Pathol., 104(9): 853860, DOI: 10.1023/A:1008624106269

Robson, A.D. \& Pitman, M.G. (1983). Interactions between nutrients in higher plants (pp. 147-180). In: Inorganic Plant Nutrition. Läuchli A., Bieleski R.L. (Eds.). Encyclopedia of Plant Physiology, Pirson A., Zimmermann M.H. (Eds.), New Series, Vol. 15A. Springer-Verlag, New York. 
Saleh, M.M.S. \& Eman, A.A. (2003). Improving the productivity of 'Fagri Kalan' mango trees grown under sandy soil conditions using potassium, boron and sucrose as foliar spray. Ann.Agric.Sci., Ain Shams Univ., 48(2): 747-756.

Salisbury, F.B. \& Ross, C.W. (1992). Plant physiology, $4^{\text {th }}$ Ed., Wadsworth Pub. Co., Belmont, California, pp. 384-386.

Sampaio, V.R., Scarpare Filho, J.A. \& Kluge, R.A. (1999). Distúrbios fisiológicos da manga: efeito da aplicação de $\mathrm{Ca}$ em pulverização foliar. Sci.Agric., 56(2): 459-463, Piracicaba, DOI: 10.1590/S010390161999000200028

Sanewski, G.M. (Ed.) (1991). Custard apples - cultivation and crop protection. Information series Q190031, Queensland Department of Primary Industry, Brisbane, Australia.

Sankar, C., Saraladevi, D. \& Parthiban, S. (2013). Effect of foliar application of micronutrients and sorbitol on fruit quality and leaf nutrient status of mango cv. Alphonso. Asian J.Hort., 8(2): 714-719.

Santos Filho, H.P., Tavares, S.C.C. de H., Matos, A.P., Costa, V.S. de O., Moreira, W.A. \& Santos, C.C.F. dos (2002). Doenças, monitoramento e controle. In: Genu P.J.C. and Pinto A.C. de Q. (Eds.) A Cultura da Mangueira. Embrapa Informação Tecnológica, Brasilia, Brazil, pp. 300-352.

Saran, S.L. \& Kumar, R. (2011). Boron deficiency disorders in mango (Mangifera indica): field screening, nutrient composition and amelioration by boron application. Indian J.Agric. Sci., 81(6): 506-510.

Sarker, B.C. \& Rahim, M.A. (2012). Effects of doses and splits of fertilizer application on harvesting time, yield and quality of mango cv. 'Amrapali'. Bangladesh J.Agric.Res., 37(2): 279-293, DOI: 10.3329/bjar. v37i2.11231
Saúco, V.G. (2004). Mango production and world market: Current situation and future prospects. Acta Hortic., VII International Mango Symposium, 645: 107-116, DOI: 10.17660/Acta Hortic.2004.645.7

Schaffer, B., Larson, K.D., Snyder, G.H. \& Sanchez, C.A. (1988). Identification of mineral deficiencies associated with mango decline by DRIS. HortSci., 23(3): 617-619.

Schmidt, W. (1999). Mechanisms and regulation of reduction-based iron uptake in plants. New Phytol., 141: 1-26, DOI: 10.1046/j.1469-8137.19 99.00331.x

Schmutz, U. \& Ludders, P. (1993). Physiology of saline stress in one mango (Mangifera indicaL.) rootstock. Acta Hortic., IV International Mango Symposium, 341: 160-167, DOI: 10. 17660/Acta Hortic.1993.341.16

Schmutz, U. (2000). Effect of salt stress $(\mathrm{NaCl})$ on whole plant $\mathrm{CO}_{2}$-gas exchange in mango. Acta Hortic. VI International Symposium on Mango, 509: 269-276, DOI: 10.176 60/Acta Hortic.2000.509.29

Sharma, R.R. \& Singh, R. (2009). The fruit pitting disorder - a physiological anomaly in mango (Mangifera indica L.) due to deficiency of calcium and boron. Sci.Hortic., 119(4): 388-391, DOI: 10.1016/j.scienta.2008.08.023

Shinde, A.K., Dabke, D.J., Jadhav, B.B., Kandalkar, M.P. \& Burondkar, M.M. (2006). Effect of dose and source of potassium on yield and quality of 'Alphonso' mango (Mangifera indica). Indian J.Agric. Sci., 76(4): 213-217.

Shorter, A.J. \& Joyce, D.C. (1998). Effect of partial pressure infiltration of calcium into 'Kensington' mango fruit. Aust.J.Exp.Agric., 38(3): 287294, DOI: 10.1071/EA97115

Siddiq, M., Brecht, J.K. \& Sidhu, J.S. (2017). Handbook of mango fruit: production, postharvest science, processing technology and nutrition. Wiley-Blackwell, ISBN: 978-1-11901435-5, Oxford, UK. 
Silberbush, L.F. (2002). Response of maize to foliar vs. soil application of nitrogen phosphorus-potassium fertilizers. J. Plant Nutr., 25(11): 2333-2342, DOI: 10.1081/PLN120014698

Silva, C.R., de R. (1997). Fruticultura tropical, mangicultura, tecnologia de produção. UFLA/FAEP, Lavras-MG, Brasília.

Silva, A.V.C., da \& Menezes, J.B. (2001). Caracterização físico-química da manga 'Tommy Atkins' submetida a aplicação de cloreto de cálcio pré-colheita e armazenamento refrigerado. Sci.Agric., 58(1): 67-72, DOI: $10.1590 / S 0103-90162001000$ 100012

Silva, E.M. da, Pinto, A.C. de Q. \& Azevedo, J.A. de (1996). Manejo da irrigação e fertirrigação na cultura da mangueira. Planaltina: EMBRAPACPAC, $1996 . \quad 77 \mathrm{p}$. (EMBRAPACPAC. Documentos, 61).

Silva, D.J., Quaggio, J.A., Pinto, J.A.C., Pinto, A.C.Q. \& Megalhaes, A.F.J. (2002). Nutrição e adubação. In: A Cultura da Mangueira. Embrapa Informação Tecnológica, Brasília, Brazil, pp. 191-221.

Singh, Z., Malik, A.U. \& Davenport, T.L. (2005). Fruit drop in mango. Hortic.Rev., 31: 111-154.

Singh, R.R. \& Rajput, C.B.S. (1977). Effect of various concentrations of zinc on vegetative growth characters, flowering, fruiting and physicochemical composition of fruits in mango (Mangifera indica L.) cv. Chaunsa. Hary.J.Hort.Sci., 5(1-2): 10-14.

Singh, M.P. \& Saxena, P.K. (1994). Deficiency and excess feeding signs of macroelements on mango (Mangifera indica L) cv. Dashehari. Recent Horticulture, 1: 30-35.

Sousa, D.M.G., de, Lobato, E. \& Rein, T.A. (2004). Adubação com fósforo. In: Sousa, D.M.G., Lobato, E. (Eds.) Cerrado: correção do solo e adubação. $2^{\text {nd }}$ Ed., Embrapa
Informação Tecnológica, Brasília, Brazil, pp. 147-168.

Stassen, P.J.C., Mostert, P.G. \& Smith, B.L. (1999). Mango tree nutrition. A crop perspective. Neltropika Bulletin (South Africa), 303: 41-51.

Stevenson, F.J. (1986). Cycles of soil: carbon, nitrogen, phosphorus, sulfur, micronutrients. Wiley-Interscience, ISBN 10: 0471822183/ISBN 13: 9780471822189, New York.

Subramanyam, H., Krishnamurthy, S., Subhadra, N.V., Dalal, V.B., Randhawa, G. \& Chacko, E.K. (1971). Studies on mineral breakdown, a physiological ripening disorder in 'Alphonso' mangoes (Mangifera indica L.). Tropical Sciences, 13: 203-211.

Tisdale, S.L., Nelson, W.L. \& Beaton, J.D. (1985). Soil fertility and fertilizers. $4^{\text {th }}$ Ed., Macmillan Publishing Company, New York.

Trehan, S.P. \& Sekhon, G.S. (1977). Effect of clay, organic matter and $\mathrm{CaCO}_{3}$ content on zinc adsorption by soils. Plant Soil, 46: 329-336.

Uchida, R. (2000). Essential nutrients for plant growth: nutrient functions and deficiency symptoms. In: Plant Nutrient Management in Hawaii's Soils, College of Tropical Agriculture and Human Resources, University of Hawaii at Manoa, 4: 31-55.

Usman, M., Fatima, B., Khan, M.M. \& Chaudhry, M.I. (2003). Mango in Pakistan: a chronological review. Pak J. Agri.Sci., 40(3-4): 151-154.

Van Eeden, S.J. (1992). Calcium infiltration as a possible postharvest treatment to increase storage potential of mango fruit. South African Mango Growers' Association Yearbook, 12: 26-27.

Vuuren B.P.H.J. \& Stassen, P.J.C. (1997). Seasonal uptake of macro elements by young bearing 'Sensation' mango trees. Acta Hortic., 455: 351-358, DOI: 10.17 660/ActaHortic. 1997.455.23

Wadt, P.G.S., Silva, D.J., Maia, C.E., Tome, J.B., Pinto, P.A.D. \& 
Machado, P. (2007). Modelling of functions in calculating DRIS indices. Pesq.Agropec.Bras., 4(1): 57-64, DOI: $10.1590 /$ S0100-204X20 07000100008

Wahdan, M.T., Habib, S.E., Bassal, M.A. \& Qaoud, E.M. (2011). Effect of calcium chloride and gibberellic acid on storability of "Succary Abiad" mango fruits under cold storage. J.Am.Sci., 7(5): 493-501, DOI: 10.75 37/marsjas070511.66

Weir, R.G. \& Cresswell, G.C. (1995). Plant nutrient disorders. Volume 2: Tropical Fruit and Nut Crops. Inkata Press, Melbourne, Australia.

Welch, R.M., Allaway, W.H., House, W.A. \& Kubota, J. (1991). Geographic distribution of trace element problems (pp. 31-57). In: Micronutrients in Agriculture, $2^{\text {nd }}$ Ed., Mortvedt, J.J., Cox, F.R., Shuman, L.M., Welch, R.M. (Eds.). SSSA, Madison, WI, DOI: 10.2136/sssabo okser4.2ed.c2

Xiuchong, Z., Guojian, L., Jianwu, Y., Shaoying, A. \& Lixian, Y. (2001). Balanced fertilization on mango in southern China, Better Crops International, 15(2): 16-20.
Xu, F.S., Wang, Y.H. \& Meng, J.L. (2001). Mapping boron efficiency gene(s) in Brassica napus L. using RFLP and AFLP markers. Plant Breeding, 120:319-324, DOI: 10.1046/j.1439-0523.2001.00583.x

Yan, B. \& Hou, Y. (2018). Effect of soil magnesium on plants: a review. IOP Conf. Ser.: Earth Environ.Sci., 170(2): 022168, DOI: 10.1088/17551315/170/2/022168

Young, T.W. (1957). 'Soft nose', a physiological disorder in mango fruits. Proc.Fla.StateHort.Soc., 70: 280-283.

Young, T.W., Koo, R.C.J. \& Miner, J.T. (1962). Effects of nitrogen, potassium and calcium fertilization on 'Kent' mangoes on deep, acid, sandy soil. Proc.Fla.StateHort.Soc., 75: 364-371.

Young, T.W. \& Koo, R.C.J. (1969). Mineral composition of Florida mango leaves. Proc.Fla.StateHort. Soc., 82: 324-328.

Zia, M.H., Ahmad, R., Khaliq, I., Ahmad. A. \& Irshad, M. (2006). Micronutrients status and management in orchards soils: applied aspects, Soil Environ., 25(1): 6-16. 